\title{
Gallivanting Round the Globe: Translating National Identities in Henry $V$
}

\author{
Vicent Montalt / Pilar Ezpeleta \\ Jaume I University \\ montalt@uji.es / ezpeleta@uji.es \\ Miguel Teruel \\ University of Valencia \\ miguel.teruel@uv.es
}

\begin{abstract}
In this article we shall be looking at the character of MacMorris in Henry $\mathrm{V}$, and at his small but important role in the four captains' scene'. We shall explore some of the historical, cultural, political, dramaturgical and linguistic complexities of his portrayal of Irishness as a necessary preliminary study to its translation into other languages, both for the printed page and for the stage. Spanish and Catalan translations of the scene will be briefly analysed in what we hope will be the framework of a wider, multilingual preoccupation: how does national identity translate in a global context? How does —or can-MacMorris speak in other languages?
\end{abstract}

\section{Introduction}

Welch. Captaine Mackmorrice, I thinke, looke you, vnder your correction, there is not many of your Nation.

Irish. Of my Nation? What ish my Nation? Ish a Villaine, and a Basterd, and a Knaue, and a Rascall. What ish my Nation? Who talkes of my Nation? 
(Henry V Folio text 1237-1242)

MacMorris, gallivanting round the Globe, whinged to courtier and groundling who had heard tell of us

as going very bare of learning, as wild hares, as anatomies of death:

"What ish my nation?"

And sensibly, though so much later, the wandering Bloom replied, "Ireland," said Bloom, "I was born here. Ireland."

(Seamus Heaney “Traditions” Wintering Out 1972)

The words of MacMorris, the Irish Captain in the English army of Henry $V$, are heard again in "Traditions", a poem by Seamus Heaney from his 1972 collection, Wintering Out. Heaney presents him "gallivanting round the Globe", both as the first renowned Stage Irishman in English theatre - the only one in Shakespeare's plays - and as the quintessential Irish migrant exiled from his country and dispersed round the world. The poem plays with literary voices to discuss the clash of traditions ingrained in Irish identity, the bulling of the Irish guttural muse by the alliterative English tradition of Medieval and Elizabethan literature, represented by William Shakespeare and Edmund Spenser.

MacMorris's high-strung question about his national identity is meant to draw attention to an English stereotyped version of Irishry, that of the comic buffoon, easily moved to pique in his wounded national pride. But Heaney answers the question through the voice of Leopold Bloom, the Jewish Irish Everyman of James Joyce's Ulysses. "Ireland. I was born here. Ireland". In the Cyclops episode of the novel, at Barney Kiernan's pub, Bloom is confronted by The Citizen, a one-eyed Irish bigot who denies his Irishness. And his dignified retort is used by Heaney in his poem to open the way for the possibility and the potency of another tradition, that of Irish writers writing in English without and beyond the literature of England, and forging in the process a new national conscience of belonging in an independent culture ${ }^{2}$.

\section{Henry V's Englishness}

Eight of the nine histories written by Shakespeare in the 1590s are dedicated to the hundred years leading up to the establishment of the Tudors on the English throne. They 
are an account of the history and politics of the English monarchy, and represent an extended dramatized ideological construction of the origins of the political situation in which their Elizabethan spectators found themselves. The best of them were conceived and understood by their more thoughtful spectators as relevant to their own historical moment, reminding them as they did of contemporary social and political problems.

Henry $V$ might have made a brilliant political closure to this decade. It has been regarded as an eloquent celebration of the idea of national unity (Hump, 1975), and "a propaganda-play [...] heavily orchestrated for the brass" (Rossiter, 1954: 165). The play has also been understood as a resetting of both the popular mythology about Henry and the standard ideology of its time (Gurr, 1992: x). On the surface, it presents a nationalistic triumphalism and a glorification of Henry as a great conquering hero, while through the story itself there runs a strong hint of scepticism about the nature of his victories and his kingdom, which can sustain a far wider range of readings than the merely patriotic. Recent criticism has emphasized fissures within the semblance of national unity, as well as resistances to unifying ideology.

The construction of national unity was a timely issue in 1599, and the four captains' scene explores the contradictions of what could be seen as an effortless incorporation ${ }^{3}$. Wales must have seemed the most tractable issue, for it had long been united to England, and the English church and legal system had been imposed. Henry V and the Tudors could indeed have claimed to be Welsh. Once Elizabeth suppressed any discussion about who should succeed her on her throne in the decade before her death in 1603, James VI of Scotland was the obvious choice. And that raised the possibility of England being united to Scotland. Ireland remained the great problem - the problem that was on the point of being resolved in 1599 by Essex. Bate (2010:14) points out that "[i]n the chorus of the fifth act, the Earl of Essex is seemingly celebrated because as the audience is watching the play in London in 1599 he is broaching the Irish on his sword". According to him, Spenser's A View of the Present State of Ireland is a good example of how England construed the Irish as "anatomies of death" and as "villains and bastards and knaves and rascals" (2010: 13-15).

The Irish population was overwhelmingly Catholic and liable to support a continental invader. Resistance to English rule proved irrepressible, despite - or more probably because of - the many atrocities committed against the people — such as the slaughter of all six hundred inhabitants of Rathlin Island in 1575. The assumption that the Irish were a barbarous and inferior people was so ingrained in Elizabethan England that it seemed only a natural duty to subdue them and destroy their culture. In the persistent Irish challenge to the power of the Elizabethan state much more than national identity was at stake and it should be related to the most strenuous challenge to English unity in Henry $V$. 


\section{The four captains' scene in Henry $V$}

As a history play, Henry $V$ draws indisputably on both Holinshed's Chronicles (1587) and Hall's The Union of the Two Noble and Illustre Families of Lancaster and York (1548). In addition, "Shakespeare's acquaintance with half a dozen other accounts of Henry's reign has been claimed by one scholar or another." (Taylor, 1982: 28). It is interesting to note that the four captains' scene has no proximate source in Holinshed, Hall or any other accounts of Henry's reign. This is perhaps revealing of Shakespeare's intentions to problematize national identity and unity in the play. However, it is difficult to say whether MacMorris is fully Shakespeare's own creation or not. Maley (1997a) argues that he may not be and refers to the medieval writer Giraldus Cambrensis, who wrote The Topography of Ireland and The Conquest of Ireland, both in Latin, which were later translated into English and used by Holinshed as sources for his Chronicles. In them his uncle Maurice Fitzgerald says:

Whie then doo we tarie? And wherefore doo we so linger? Is there anie hope of releefe from home? No no, the matter is otherwise, and we in woorse case. For as we be odious and hatefull to the Irishmen, even so we now are reputed: for Irishmen are become hatefull to our owne nation and countrie, and so we are odious both to the one and the other. (Maley, 1997: 32)

Maley points out that "Gerald's Maurice Fitzgerald bears a striking resemblance to Shakespeare's 'Irish' captain” MacMorris (son of Maurice). According to Maley:

[t]he standard interpretation is that MacMorris, as an Irishman, a native of a country colonised by England, is less comfortable with his identity than his fellow captains. But the episode can be viewed in a different light if we look at a likely source in Holinshed" (2003b: 49)

He argues that MacMorris belonged to the Old English society - the first group of English settlers who went to Ireland and were both Anglo-Norman and Anglo-Irishand found himself "in that third space between native and colonizer" (2003b: 29).

We could add that there is also a striking resemblance between Maurice Fitzgerald's "No no, the matter is otherwise" and Fluellen's "Look you, if you take the matter otherwise than is meant" in his response to MacMorris (3.3.66-67). In this particular sequence, we hear the English, the Welsh, the Scottish and the Irish (these are the speech prefixes they are given in the Folio) elicit an often condescending affection mixed with admiration, contempt and rivalry regarding their knowledge of "the disciplines of war", and a sense of hesitation concerning their supposed brotherhood, their common objectives and their ultimate motives.

Gower, the English Captain, says of MacMorris: "The Duke of Gloucester, to whom the order of the siege is given, is altogether directed by an Irishman, a very valiant gentleman, i'faith" (3.3.10-12). In sharp contrast, in the next speech Fluellen will brand him an "ass" (3.3.15). Objecting to the military tactic advanced by MacMorris to plant 
mines under the besieged fortifications of Harfleur, Fluellen tries to engage MacMorris in a debate concerning military theory, in which he clearly intends to display his learning in a discourse about Roman military discipline. MacMorris rebuffs him, claiming very sensibly that the midst of a siege "is no time to discourse" (3.3.48). Patriotic feelings soon rise to the surface, as Fluellen retorts with his infuriating provocation: "Captain MacMorris, I think, look you, under your correction, there is not many of your nation" (3.3.61-62). And then MacMorris interrupts in a complex mixture of anger, irony and parody: "Of my nation? What ish my nation? Ish a villain and a bastard and a knave and a rascal? What ish my nation? Who talks of my nation?" (3.3.63-65).

The most established interpretation reads that MacMorris's speech shows "that his loyalties to the English crown do not submerge his own" (Quinn, 1966: 161). Philip Edwards's revisionist interpretation argues that MacMorris's retort is usually misread. He takes MacMorris to mean:

What is this separate race you're implying by using the phrase 'your nation'? Who are you, a Welshman, to talk of the Irish as though they were a separate nation from you? I belong in this family as much as you do. (1979: 75-76)

He is not, according to Edwards (1979), daring Fluellen to make yet another retort about his people or nation, but rather, bristling at the "sense of discrimination" implied by the Welshman's remarks, as if Ireland were "a separate nation from the great (British) nation which the Welshman apparently thought he belonged to" (Edwards, 1979: 75-76) ${ }^{4}$. MacMorris's nation may be in doubt not because he is Irish, but precisely because he is English. The matter could well be otherwise, as Maley has pointed out:

As an Old Englishman, a descendant of the twelfth-century English settlement in Ireland, he could claim dual nationality. MacMorris, or 'son of Morris', belongs to a clan which traces its ancestry back to the so-called 'Anglo-Norman' conquest. The MacMorris episode in Henry $V$ offers one example of the way in which the Irish section of Holinshed's Chronicles, a peculiar mixture of medieval and early modern 'Old English' myths and anecdotes, came to be a source for a text celebrating a new kind of Englishness from which that community were to be excluded. (2003a: 51)

If we agreed with Edwards, we could also agree with Dollimore and Sinfield (2002: 228) and see the union in peace at the end of the play as a representation of the attempt to conquer Ireland and the hope for the unity of Britain (Edwards, 1979: 74-86). The play would thus offer a displaced, imaginary resolution of one of the state's most intractable problems, and could be thought of as a merely deluded and mystifying ideological fantasy.

However, viewing the play in such terms would not be consistent with the indeterminacy of MacMorris's speech - its openness to two contradictory readings is an assertion and remembrance of his national origins, on the one hand, and a blotting 
out of those origins, on the other - and with the antagonism and rivalry shown between Fluellen and MacMorris. Taylor corroborates this conjecture:

What can hardly be disputed is the playwright's preoccupation with Irish affairs: from Captain MacMorris, Shakespeare's only Irish character (3.3), to the "kern of Ireland" and "foul bogs" (3.7.51-55), through Pistol's "Calin o custure me!" (4.4.4) to the general "from Ireland coming" (5.0.31), the revealing textual error in the Folio's "So happy be the issue, brother Ireland" (5.2.12), and Henry's promise to Catherine that "England is thine, Ireland is thine, France is thine" (5.2.230-231). This preoccupation, the dramatist could confidently expect his audience to share. (1982: 7).

Just before the king and his train enter, our sequence closes with three revealing comments by each member of the quartet. MacMorris, who did not want to speak at the beginning - "It is no time to discourse" (3.3.48) - ends up with a violent threat addressed to Fluellen: "I will cut off your head" (3.3.73). This highly emotional voice is counter-balanced by a condescending remark from the hitherto silent Gower "Gentlemen both, you will mistake each other" (3.3.74). The English voice seems to be uttered from the place of an observer who witnesses conflict from above and apparently does not take part in it. Jamy's closing words are ambivalent. In "that's a foul fault" (3.3.75), 'that' could either point to mistaking each other or to cutting Fluellen's throat. Finally, Fluellen is given the power and authority to close the sequence by addressing MacMorris directly in a defiant attitude.

These characters and their dialectal variations are traditionally interpreted in comic terms. Wales (2001: 202) points out that "[t]heir speeches together are so rambling and repetitive that it is very clear that Shakespeare's English audiences would be meant to smile somewhat patronizingly at their discourses: a literary tradition that has continued until the twentieth century". That may well be true among English audiences, but not necessarily among other audiences. If we analyse the scene carefully and frame it within the whole play we come to understand that there are three parallel and complementary dramatic levels in it:

a) Henry and his followers, the church, the traitors, and the king of France and his followers, all of whom represent the major historical events concerning England's exploits in France. They often speak the language of high politics and power.

b) Falstaff's companions - the more popular characters of Pistol, Bardolph, Nym, Hostess, Boy, etc.- - who speak the language of the street and tavern, and who are often used to counterbalance the first level by means of comedy.

c) The third level is occupied by the four captains, who are placed neither in the context of the palace nor the tavern, but in the battlefield, directly involved in military action. It is in this third space that we identify the national and ideological conflicts these four characters bring about. 
These three dramatic levels can best be seen in specific echoes of emblematic expressions such as "to the breach". In 3.1.1, Henry encourages his followers in the middle of the battlefield: "Once more unto the breach, dear friends, once more". In the following scene (3.2.1), Bardolph echoes and parodies in comic tone Henry's words: "On, on, on, on, on! To the breach, to the breach!" provoking the Boy's famous response "Would I were in an alehouse in London. I would give all my fame for a pot of ale, and safety" (3.2.10-11). The third dramatic level can be seen in how MacMorris repeats the expression: "It is no time to discourse [...] the trumpet call us to the breach" (3.3.48-51).

If we now turn our attention to cultural contexts other than the English, the 'patronizing smiles' no longer make sense. For example, when this sequence is staged for an Irish audience, it becomes impossible to keep the same kind of derision of the Other. The same can be said when this play is translated into another language and staged in another culture. The terms need to be altered, or even inverted. The whole sequence focuses its dramatic energy on two of the captains: Fluellen and MacMorris. The way Fluellen changes his rhetoric and attitude may be revealing. He sounds gentle and kind when talking to Gower about Jamy, or when answering Jamy. But when he addresses MacMorris, he sounds boastful, provocative and condescending, as if he were already aware of MacMorris's sensitivity and is goading him to an angry outburst. There seems to be no hint of comedy in the way Fluellen and MacMorris speak to each other, except when MacMorris cuts into Fluellen's long-winded discourse on Roman military theory - surely this would have drawn at least a knowing smile from the audience?

Gurr has pointed out that no play of Shakespeare's makes so much use of differences in language and has more language barriers. Fluellen's, MacMorris's and Jamy's non-standard English put up a considerable show of distance and noncommunication (1992: 36) which could be considered as part of the general emphasis given in that act to the quarrelsome division of soldier from soldier, from nation to nation, in Henry's army. (1992: 32). However, the misunderstandings between Fluellen and MacMorris - "you take that matter otherwise than is meant" (3.3.66-67) — are not linguistic but ideological. There are no traces in their lines that could let us infer that they "mistake each other" (3.3.74) because of their different accents, but rather because of their antagonism - "you do not use me with that affability as in discretion you ought to use me" (3.3.68-69); their "disputations [...] concerning the disciplines of war" (3.3.38-39); and their ultimately different motives. In this sense, alienation is signaled by the different accents (Zimbardo, 1964: 165).

Language can draw attention to dissimilarity and even estrangement amongst individuals, communities and nations, and dialects and accents could be regarded as mere labels which serve to identify types which are different. Their function here is to illustrate the false concors discordia which the ideal myth makes of the state. The accents of Fluellen and MacMorris are more or less pronounced depending on whom they are addressing and to what purpose. This opposes any idea of a consistent monologist comic stereotyped image of the characters. The overall function of the four 
captains' scene and the multiple voices we hear they speak has often been thought of as superficially comic or even patronizing, but —as we read it - it is both dramatic and ideological in complex ways.

There are three main reasons to look carefully at this scene from the point of view of translation. Firstly, the presence of dialect and the fact that dialect is an uncommon feature of Shakespeare's dramatic language. In the whole of Shakespeare's dramatic corpus, dialect is very rarely used to mark national identities. For example, there are other Welsh captains, such as the one in Richard II (2.4), but they do not speak a marked dialect:

Captain: 'Tis though the king is dead. We will not stay The bay trees in our country are all withered And meteors fright the fixed stars of heaven. The pale faced mood looks bloody on the earth, And lean looked prophets whisper fearful change.

Secondly, the function of dialect in this scene, and the fact that the scene we are concerned with does not produce a comic effect. As we have already pointed out, we can distinguish three different levels of dramatic discourse in this play. The four captains are marked individually by dialectal traits not to deform national stereotypes and provoke easy comic effect, but to make it clearly audible and visible that we are dealing with national identities in conflict.

Thirdly, the need to strike a balance between two opposed tensions —one towards the source culture, the other towards the target culture - in such a context-bound and language-bound issue as national identity.

\section{The four captains' scene in translation}

As we have established, dialect in this sequence is subordinate to dramatic function. Dialectal marks respond more to political implications in Shakespeare's times than to the medieval historical frame of reference that he took from Hall and Holinshed. They function as an antithesis of the national standard represented by the prestigious variety spoken in London, and used by the king. Each of the captains is marked by a few spelling licences that are meant to reflect dialectal variations: Fluellen's greeting 'Godden' (good day), the devoicing of $/ \mathrm{v} /$ and $/ \mathrm{b} /$ in words like 'falorous' and 'porn' (born), the discourse tag 'look you', and the oath 'by Cheshu' (Jesus); Jamy has the Northern 'bath' for 'both', 'ligge' (lie) and 'sal' for 'shall'; and MacMorris has distinctive fricative consonants: 'Chrish', 'tish' ('tis), 'ish' (is) (Wales, 2001: 201).

The difficulty of achieving dialectal equivalence in translation will be apparent to anyone who has translated for the stage. The representation in a source text of a particular dialect creates an inescapable problem for the translator: which target dialect to use? Or whether to use one at all? Hatim and Mason (1990: 40-41) point out three different ways of approaching the problem: 
a) Trying to find a real diatopic variety in the target language. However, it is impossible to find equivalent varieties between two different languages and the translator runs the risk of creating unintended effects.

b) Translating into an imaginary dialect. This strategy involves the alteration of pronunciation features or any other feature, in order to mark the distance from the standard variety.

c) Rendering source text dialect by target language standard. This procedure has the disadvantage of losing the special effect intended in the source text.

Two well-known translations ${ }^{5}$ — Luis Astrana's into Spanish and Salvador Oliva's into Catalan - will suffice to illustrate the second and third approaches proposed by Hatim and Mason. In a footnote at the beginning of the sequence, Astrana comments on the language these characters use:

This character [Fluellen] as well as MacMorris and Jamy [...] pronounce and build their English in a detestable way. It was then necessary to imitate their jargons so as to be able to give a gist of the original. However, I have done so now and then, and not in all instances, because otherwise it would sound "enfadoso" [annoying, tedious, awkward]. ${ }^{6}$

In the following passage by Fluellen, we can see how Astrana's strategies lead him to specific choices at the micro-level:

¡A las minas! Tecitle al tuque que no es tan bueno ir a las minas; porque, feréis, las minas no están según las leyes te la guerra; las canfitates no son suficientes; porque, feréis, el adversario (potéis sostener eso telante tel tuque, feréis) ha cafado por su cuenta cuatro metros de contraminas abajo. ¡Por Chesús, creo que hará saltar a totos, si no tomamos mejores metitas!

His treatment of spelling licences is literal — " $t$ " and " $v$ " become " $d$ " and "f" " $d$ " and "v" become " $t$ " and " $\mathrm{f}$ " respectively; and "Jesús" becomes "Chesús" — and does not belong to any real dialect. The result is highly deformed language that does not correspond to any cultural reality in the target culture.

In Oliva's footnote at the beginning of the sequence, the translator comments on his translation strategies in the following terms:

Fluellen is Welsh and Shakespeare deforms his phonetics. We have chosen to leave the full character of Fluellen with a normal Catalan accent. However, it is clear that on the stage he should speak with an accent of another language. Such an accent, in Catalan, should be invented, consistent, and should affect just a few phonemes. We have not marked it because we don't want to impose just one solution. Rather, we would like to leave them all open. Fluellen's pintoresque syntax and anacoluthon have been respected in this translation. ${ }^{7}$

Later on, when MacMorris and Jamy appear, the translator makes the following comment in a footnote: 
MacMorris is Irish and Jamy is Scottish. They present the same problem as that described in footnote number 4 regarding Welsh Fluellen.

In the same passage by Fluellen, these are Oliva's choices:

¿A les mines? Digueu al duc que no està gaire bé això d'anar a les mines; perquè, mireu, les mines no lliguen gaire amb les ordenances militars. No són prou còncaves; perquè, mireu, l'enemic (ja li ho podeu dir al duc) mireu: ha excavat quatre iardes per sota de les nostres mines. Jesús! Em sembla que volarem tots, si no ens organitzem millor.

He neutralizes all spelling variations into a standard spelling that masks the dialectal marks of the characters.

Schleiermacher's famous discussion of the translator's choice between moving the reader towards the author (foreignizing) or the author towards the reader (domesticating) — which was taken and developed further by Venuti in the 1990s - can be useful in our research. Astrana's intention is as vague as "to give a gist of the original" (see above) and seems to be driven by foreignizing, in Schleiermacher's terms. But the result is a target text in which the four captains sound rustic, awkward and even foolish. In fact, they may even provoke contemptuous laughter in the audience because of their absurdity. Oliva's translation does not attempt to reproduce the spelling licences that mark the characters geographically in the source text. In his translation the audience does not seem to be moved towards the author. His standard Catalan for MacMorris and the other three captains has a clear motivation: not to impose just one solution and leave it open for the actors and directors to make their own choice.

Both foreignization and domestication seem to be problematic as far as translating dialect and national identity are concerned. When watching and hearing Henry $V$ on the stage, a Catalan or Spanish audience will most likely want to watch a play about British history, and of course, not an adaptation to the Spanish context. This would be a strategy of translation whereby the text is not appropriated/domesticated, but rather the opposite: the audience is taken to the source context and shown the other culture, the other history, the other politics, etc.

But in Henry $V$ Shakespeare is not talking only of medieval history, politics, monarchs and societies; he is also referring to his own times. This sense of substantiation, of actualization, is intrinsic to theatre, and translators, actors and directors are aware of this need. So what can or should be done to these geographical variations of the language spoken by MacMorris, Fluellen, and the other captains? Would it be advisable to avoid any dialectal marks? Or to provide the target text with some marks that can guide actors and directors?

Trying to find a real diatopic variety in the target language is risky because it involves unavoidable asymmetries between the two languages and cultures. In the case of translation into Catalan and Spanish, several possibilities are available ${ }^{8}$ - such as using existing dialects and national tensions and conflicts in the target contexts - and 
can be - and indeed should be - explored not only by translators, but also by directors and actors — and ideally by all of them in collaboration.

\section{Discussion and conclusions}

In the four captains' scene, Shakespeare exploits phonetic traits and dialectal expressions as well as lexical anomalies, and creates a hybrid text/scene in which "superior" English interacts with other accents, and in which the asymmetrical relations and tensions between the cultures involved are shown. Translators have to decide whether to show these tensions or not, and how to do so. They also have to decide whether to take the audience to the text or the text to the audience, or both. The process of interpretation, selection and relocation is ideological and will inevitably provoke controversy. And even more so in theatrical translation, where translation not only implies choice, but also, paradoxically, requires enabling choice to directors, actors, etc.

From such a perspective, another way of approaching the problem, not taken into account by Hatim and Mason, is one that seeks to bridge the gap between foreignization and domestication, one that moves the question from the linguistic to the theatrical. Since it is obviously impossible, as Hatim and Mason quite rightly say, "to find equivalent [dialectal] varieties between two different languages" (1990: 40-41), why not try to reconstruct the dramatic function of these dialectal usages by resorting to the rich range of non-verbal codes that are available in performance?

As we have tried to demonstrate, Astrana's "imaginary" dialect in Spanish is found wanting. His procedure leads inevitably to comic effect, and turns dialect speakers into rustic laughing stocks, devoid of the national dignity and challenging reclamation we hear in MacMorris. In the Catalan translation, Oliva's neutralization runs the risk of "losing the special effect intended in the source text" (again Hatim and Mason, 1990: 40-41), even though his solution, at least, keeps faith with the original function of the scene.

What we are suggesting is to combine Oliva's strategy - the use of standard language, thus avoiding a specific dialectal choice for translation - with sufficient dramaturgical information in paratext to enable the various directors and actors who will use our text for their various stage productions to decide for themselves how they wish to conduct the scene. Depending on their (national) interests, they might choose to highlight or play down the challenge of MacMorris's question, and they should be able to do so with our text if our translation, as we believe, is to be as dramatically charged with the powerful ambiguity and capacity of the original.

This is why we feel the need to claim paratextual space (in the form of 'scene annotations' in a written translation, or as 'dramaturgical intervention' in the case of a given stage production during rehearsals) to include and provide all the relevant information, that might otherwise go unnoticed, if we were to opt for a single choice of target dialect, or if we were simply to neutralize the language of the scene. 
This claim for an open space where discussion may enrich the possibilities of the original text in any other language is not a sign of defeat on the part of the translator. On the contrary, it is a positive response to the awareness of the potency of the original. Equipped with this non-prescriptive information, directors and actors will be better prepared to search for dramatic function and effect by non-verbal means, and to probe into questions of national conflict without the heavy yoke of an impossible linguistic choice.

We shall listen in our language to an Irish captain in an English play. We will not turn him into a rustic comic character by attempting to translate his dialect. But we believe that the function of his dialect may be reconstructed by focusing on other codes: details of dress, gesture, conventional hints of cultural and national identity that will invite audiences to partake in the wonderful incoherence that is natural and essential to theatrical art. MacMorris in Spanish with a touch of Catalan or Basque attitude? For MacMorris is of Irish nation when staged in English, but he may sound and look slightly familiar in any other language by the magic of the stage.

Another aspect that translators should bear in mind when translating dialects is their status within the cultures, and more specifically, the literary and theatrical systems, involved. The use of dialect has a long tradition in English literature, which has served different purposes over many centuries. In the Spanish and Catalan traditions, on the contrary, dialects have a lower status and are less frequently exploited. The critical translation problem in the sequence we have analysed is not dialect per se. It is rather how to interpret national identities and the clashes between them in the source text, whether to transfer them to the target language and culture, and how to do so. National identities and clashes are primarily defined by the content of the dialogues and their dramatic form. And dramatic content and form are often ambivalent and elusive. Ambivalence and elusiveness are then not just translation problems, but essential attributes of the text.

Translation consists fundamentally of making choices at all levels. In this case study, and in most of Shakespeare's plays - and indeed in most translation for the stage - the real challenge is leaving possibilities for choice as wide open as possible for theatre directors and actors. And yet this openness of choice that translators should provide in the target text coexists with dramatic form, without which the target text would be shapeless and dramatically and theatrically inadequate. The challenge is leaving choice open to actors and directors and yet shaping the dramatic form as much as possible. This paradox is intrinsic not only to Shakespeare's text, but also to any form of artistic reproduction and interpretation, such as music, in which the score both offers a variety of possibilities and establishes the limits of the game, that is, its true identity.

The tensions at work in Henry $V$ can only be resolved - and always momentarilyon the clean, magic slate of the theatre, and the English stage history of the play (Smith, 2002) has paid interesting tribute to the various conflicting viewpoints. But MacMorris can also speak in any other language, and directors and audiences round the globe will 
always hear "What ish my nation?" in their own languages reverberating in their own historical and national experience.

\section{Notes}

1. 3.3.1-80. All references from the play to Gary Taylor's Oxford edition (1982). Actus Secundus in the Folio. The scene does not appear in the 1600 Quarto.

2. Corcoran (1986: 81-83). The question has become a stock reference in Irish Studies: see O’Brien (1998a,b), Steinberger (2008: 5-29).

3. Dollimore and Sinfield (2002: 228).

4. Philip Edwards (1979: 75-78) shows how an Irish captain who had been in Essex's army made a similar protest.

5. The existing translations into Spanish are: Francisco Nacente, Enrique V, 1870-1871 (translated from French. Included in Los grandes dramas de Shakespeare); Rafael Martínez Lafuente, El rey Enrique V, 1918 (translated from French. Included in Obras completas); Luis Astrana Marín, La vida del rey Enrique V, 1929 (included in William Shakespeare. Obras Completas); Rafael Ballester Escalas, Enrique V, 1962; José $\mathrm{M}^{\mathrm{a}}$ Valverde, Enrique V, 19671968 (included in William Shakespeare. Teatro completo); Manuel Pérez Estremera, Enrique V, 1969; and Lelia Cisternas de Mínguez, Enrique V, 1974.

6. Our translation.

7. Our translation.

8. English $>$ Spanish? English $>$ Barceloní?

Welsh > Galician? Welsh > Lleidatà?

Scottish $>$ Catalan? Scottish $>$ Mallorquí?

Flullen Irish $>$ Basque? $\quad$ Irish $>$ Valencià?

Capità MacMorris, pel que veig -corregiu-me si vaig errat- de la vostra nació, molts no n'hi ha. MacMorris (Balearic)

De sa meva nació! I què és sa nació meva? Sí, una perduda, una brètola, una canalla, una puta. Quina és sa meva nació? I qui parla de sa nació meva?

MacMorris (Valencian)

De la meua nació! I què és la nació meua? Sí, una perduda, una brètola, una canalla, una puta. Quina és la meua nació? I qui parla de la nació meua?

\section{References}

Folio text:

http://internetshakespeare.uvic.ca/Library/facsimile/book/SLNSW_F1/432

\section{Printed editions:}

Bate, Jonathan and Eric Rasmussen, eds., (2010): Henry V. The RSC Shakespeare. Basingstoke: Macmillan.

Gurr, Andrew, ed. (1992): King Henry V. The New Cambridge Shakespeare. Cambridge: Cambridge University Press. 
Smith, Emma, ed. (2002): King Henry V. Shakespeare in Production. Cambridge: Cambridge University Press.

Taylor, Gary, ed. (1982): Henry V. The Oxford Shakespeare. Oxford: Oxford University Press. Walter, John H., ed. (1954): King Henry V. The Arden Shakespeare. London: Methuen.

Translations cited:

Astrana Marín, Luís (1929): La vida del rey Enrique V. In William Shakespeare, Obras Completas. Madrid: Aguilar.

Oliva, Salvador (1986): William Shakespeare, Enric V. Barcelona: Vicens Vives i TV3.

Works cited:

Corcoran, Neil (1986): Seamus Heaney. London: Faber.

Dollimore, Jonathan and Alan Sinfield (2002): "History and Ideology: The Instance of Henry V'. In J. Drakakis, ed., Alternative Shakespeares. London: Routledge, 210-231.

Edwards, Philip (1979): Threshold of a Nation: A Study in English and Irish Drama. Cambridge University Press.

Hatim, Basil, and Ian Mason (1990): Discourse and the Translator. London: Longman.

Heaney, Seamus (1972): Wintering Out. London: Faber.

Hump, John (1975): "Shakespeare and History: The T. H. Searls Memorial Lecture", University of Hull, 1974. Critical Quarterly 17: 233-244.

Joyce, James (1922): Ulysses. <http://www.robotwisdom.com/jaj/ulysses/index.html>

Maley, Willy (1997a): "Shakespeare, Holinshed and Ireland: Resources and Con-texts". In M.T. Burnett and R. Wray, eds., Shakespeare and Ireland: History, Politics, Culture. New York: St. Martin's, 27-47.

(2003a): Nation, State and Empire in English Renaissance Literature: Shakespeare to Milton. Basingstoke: Palgrave Macmillan.

(2003b): "The Irish Text and Subtext of Shakespeare's English Histories". In A Companion to Shakespeare's Works: The Histories. Vol. 2. Malden, MA: Blackwell, 94124.

O’Brien, Eugene (1998a): “'What ish My Nation?': Towards a Negative Definition of Identity". Minerva 2. <http://www.ul.ie/ philos/vol2/negation.html>

Quinn, David Beers (1966): The Elizabethans and the Irish. Folger Monographs on Tudor and Stuart Civilization. Ithaca, NY: Cornell University Press.

Rossiter, Arthur Percival (1954): “Ambivalence: The Dialectic of the Histories”. In J. Garret, ed., Talking of Shakespeare. London: Hodder and Stoughton, 149-71.

Steinberger, Rebecca (2008): “'What ish My Nation?': The Blurring of National Identity in Shakespeare's Henry V, Richard II, and Spenser's A View of the Present State of Ireland". In Shakespeare and Twentieth-Century Irish Drama: Conceptualizing Identity and Staging Boundaries. Aldershot: Ashgate, 5-29.

Venuti, Lawrence (1995): The Translator's Invisibility: A History of Translation. London: Routledge.

Wales, Katie (2001): "Varieties and Variation". In S. Adamson, et al., eds., Reading Shakespeare's Dramatic Language: A Guide. The Arden Shakespeare. London: Methuen.

Zimbardo, Rose Abdelnour (1964). "The Formalism of Henry V”. In M. Quinn, M., ed., (1969). Shakespeare, Henry V: A Selection of Critical Essays. London: Macmillan, 163-170. 